\title{
Dampak Pernikahan Dini Terhadap Pendidikan Anak Dalam keluarga
}

\author{
Muhammad Ikhsanudin ${ }^{1 *}$ dan Siti Nurjanah ${ }^{2}$ \\ ${ }^{12}$ STKIP NURUL HUDA \\ *E-mail: ikhsanudin@stkipnurulhuda.ac.id
}

\begin{abstract}
Abstrak
Penelitian ini bertujuan mengetahui dampak pernikahan dini terhadap pendidikan anak dalam keluarga di Desa Nusa Bakti Kecamatan Belitang III. Penelitian ini adalah penelitian deskriptif kualitatif. Subjek penelitian ini adalah keluarga yang menikah dini di Desa Nusa Bakti, anak dalam keluarga yang menikah dini. Sumber data meliputi sumber data primer dan skunder. Teknik pengumpulan data adalah observasi, wawancara dan angket. Teknik analisis data adalah reduksi data, penyajian data dan penarikan kesimpulan. Kegiatan akhir analisis data penelitian disimpulkan Pertama: Keluarga adalah tempat pertama belajar, dukungan keluarga akan menjadikan anak yang tumbuh dengan penuh kasih sayang, percaya akan diri sendiri. Pendidikan anak di desa nusa bakti sangat baik. Kedua: Pernikahan dini sangat berdampak bagi pendidikan anak yang masih memerlukan bimbingan dari orang tua terutama orang tua yang kurang dalam memberikan kasih sayang terhadap anak, Selain itu ekonomi orang tua yang kurang memadai dapat mengganggu pendidikan anak di sekolah, kurang harmonisnya keluarga dapat mengganggu mental anak, karena orang tua yang menikah dini masih memikirkan diri mereka sendiri. Ketiga: Upaya orang tua dalam mendidik anak dalam keluarga yang menikah dini sebagai pendidik utama dalam penanaman keimanan dan pengetahuan. Orang tua yang Menikah dini telah berupaya dalam mendidik anak-anaknya dengan baik, dan menjalankan tugasnya dengan baik.
\end{abstract}

Kata kunci: Pernikahan Dini, Pendidikan Anak.

\section{PENDAHULUAN}

Pernikahan merupakan kebutuhan fitri setiap manusia yang memberikan banyak hasil yang penting. Pernikahan amat penting dalam kehidupan manusia, perseorangan maupun kelompok, dengan jalan pernikahan yang sah, pergaulan laki-laki dan perempuan menjadi terhormat sesuai kedudukan manusia sebagai makhluk yang berkehormatan. Pergaulan hidup berumah tangga dibina dalam suasana damai, tenteram, dan rasa kasih sayang antara suami dan istri. Anak keturunan dari hasil pernikahan yang sah menghiasi kehidupan keluarga dan sekaligus merupakan kelangsungan hidup manusia secara bersih dan berkehormatan. Perkawinan ialah ikatan lahir batin antara seorang pria dengan seorang wanita sebagai suami istri dengan tujuan membentuk keluarga (rumah tangga) yang bahagia dan kekal berdasarkan Ketuhanan Yang Maha Esa".

Pasal 7 Undang-undang Nomor 1 Tahun 1974 ayat (1) menyatakan bahwa "Perkawinan hanya diizinkan jika pihak pria sudah mencapai umur 19 (sembilan belas) tahun dan pihak wanita sudah mencapai umur 16 (enam belas) tahun". Ketentuan batas umur ini, seperti disebutkan dalam Kompilasi Hukum Islam pasal 15 ayat (1) didasarkan kepada pertimbangan kemaslahatan keluarga dan rumah tangga perkawinan. Ini sejalan dengan prinsip yang diletakkan UU Perkawinan, bahwa calon suami isteri harus telah masak jiwa raganya, agar dapat mewujudkan tujuan perkawinan secara baik tanpa berakhir pada perceraian dan mendapat keturunan yang baik dan sehat. Untuk itu harus dicegah adanya perkawinan antara calon suami istri yang masih di bawah umur. Pernikahan dini merupakan institusi agung untuk mengikat dua insan lawan jenis yang masih remaja dalam satu ikatan (Luthfiati,2008). 
Diteliti secara seksama, ajaran Islam tidak pernah memberikan batasan yang definitif pada usia berapa seseorang dianggap dewasa. Berdasarkan ilmu pengetahuan, memang setiap daerah dan zaman memiliki perbedaan dengan daerah dan zaman yang lain. Di sisi lain, masalah pernikahan merupakan urusan hubungan antar manusia (mu'âmalah) yang oleh agama hanya diatur dalam bentuk prinsip-prinsip umum. Tidak adanya ketentuan agama tentang batas usia minimal dan maksimal untuk menikah dapat dianggap sebagai suatu rahmat, kedewasaan untuk menikah termasuk masalah ijtihâdiah, dalam arti kata diberi kesempatan untuk berijtihad pada usia berapa seseorang pantas menikah. Hal ini sebagaimana diungkapkan Rofiq bahwa masalah penentuan umur dalam undang-undang perkawinan maupun dalam kompilasi, memang bersifat ijtihâdiah, sebagai usaha pembaharuan pemikiran figh yang lalu, meskipun demikian, apabila dilacak referensi syar'inya mempunyai landasan kuat. Remaja merupakan bibit awal suatu bangsa untuk menjadi bangsa yang lebih baik, bermartabat dan kuat.

Oleh karena itulah, masa depan suatu bangsa terletak di tangan para remaja. Saat ini problematika yang terjadi pada para remaja adalah banyaknya remaja yang ingin membina rumah tangga dengan melakukan pernikahan dini. Bila ditelusuri, banyak faktor menyebabkan remaja melakukan pernikahan dini, bisa karena pergaulan bebas akibat terjadi perkawinan diluar pernikahan. Hal lain adalah informasi yang menyimpang yang mengubah gaya pandang remaja atau bisa juga disebabkan oleh faktor ekonomi. Walaupun banyaknya faktor yang melatar belakangi pernikahan dini, akan tetapi dampak buruk yang terjadi ketika melakukan pernikahan dini lebih banyak pula. Dampak tersebut terdiri dari dampak fisik dan mental. Secara fisik, misalnya Remaja itu belum kuat, tulang panggulnya masih terlalu kecil sehingga bisa membahayakan proses persalinan. Kondisi demikian, dilatar belakangi oleh keberadaan zaman yang masih tertinggal, maka konsep pemikirannyapun tidak begitu mengarah pada jenjang kehidupan masa depan yang lebih baik.

Tradisi pernikahan zaman nenek moyang lebih teracu dengan prospek budaya nikah dini, yakni berkisar umur 15 tahun para wanita dan pria berkisar umur 20 tahun atau kurang. Perempuan yang menikah dibawah umur 20 tahun beresiko terkena kanker leher rahim, pada usia remaja sel-sel leher rahim belum tumbuh dengan matang. Kalau terpapar oleh Human Papiloma Virus (HPV) maka pertumbuhan sel akan menyimpang menjadi kanker. dr Nugroho Kampono, Sp.OG menyebutkan kanker leher rahim menduduki peringkat pertama kanker yang menyerang perempuan Indonesia, angka kejadiannya saat ini $23 \%$ diantara kanker lainnya.

Upaya pencengahan pernikahan anak dibawah umur dirasa akan semakin maksimal bila anggota masyarakat turut serta berperan aktif dalam pencengahan pernikahan anak dibawah umur yang ada disekitar mereka. Sinergi antara pemeri ntah dan masyarakat merupakan jurus terampuh sementara ini untuk mencengah terjadinya pernikahan anak bibawah umur sehingga kedepannya diharapkan tidak ada lagi anak yang menjadi korban akibat pernikahan tersebut dan anak-anak Indonesia bisa lebih optimis dalam menatap masa depannya kelak, (Alfiyah,2010). Pendidikan bagi masyarakat awam, istilah pendidikan seseringnya diidentikka dengan "Sekolah", "Guru mengajar di kelas" pendidikan pada intinya proses penyiapan subjek menuju manusia masa depan yang bertanggungjawab (Danim, 2013:4). Sedangkan menurut henderson pendidikan merupakan suatu proses pertumbuhan dan perkembangan, sebagai hasil interaksi individu dengan lingkungan sosial 
dan lingkungan fisik, berlangssung sepanjang hayat sejak manusia lahir.

Krisis moral yang terjadi di masyarakat seperti perkelahian antar pelajar, kenakalan anak, remaja putus sekolah, narkoba, miras, sex bebas, premanisme dan terorisme, bila diteliti dan dicermati penyebab utama adalah bersumber dari keluarga yang tidak sakinah (bahagia dan sejahtera lahir dan batin). Bahkan di tahun 2016 ini, salah satu setasiun Televisi mengiklankan bahwa "Indonesia Darurat Narkoba". Hal ini menjadi warning kepada setiap individu untuk mengurus keluarganya masing-masing, mengapa demikian, keluarga adalah bagian kecil dari masyarakat tetapi merupakan bagian inti suatu Negara.(Marlina, 2016, p. 29)

Keluarga merupakan bagian yang tidak dapat terpisahkan dalam kehidupan keluarga menjadi tempat pertama seseorang memulai kehidupannya. Keluarga membentuk suatu hubungan yang sangat erat antara ayah, ibu maupun anak. Hubungan tersbut terhadi dimana antar anggota keluarga saling berinteraksi. Interaksi tersebut menjadikan suatu keakraban yang terjalin di dalam keluarga, dalam keadaan yang normal maka lingkungan yang pertama yang berhubungan dengan anak adalah orang tuanya, saudara-saudaranya serta mungkin kerabat dekatnya yang tinggal serumah. Melalui lingkungan itulah anak mulai mengenal dunia sekitarnya dan pola pergaulan hidup sehari-hari, melalui lingkungan itulah anak mengalami proses sosialisasi awal.

Itulah sebabnya pendidikan dalam keluarga di sebut pendidikan yang pertama dan utama, serta merupakan peletak dari pondasi dari watak dan pendidikan anak. Oleh karena itu konsep pendidikan perlu diterapkan terutama dalam pendidikan keluarga karena pendidikan keluarga sebagai fondasi terhadap lembaga pendidikan sekolah dan luar sekolah, ataupun dalam masyarakat. Pentingnya peran orang tua dalam pendidikan anak telah didasari oleh banyak pihak. Mengasuh, membina dan mendidik anak di rumah merupakan kewajiban bagi setiap orang tua dalam usaha membentuk pribadi anak. Pendidikan di sekolah saja tidak cukup, karena orang tua juga sangat berpengaruh terhadap pendidikan anak. Sosialisasi menjadi sangat penting dalam pembentukan kepribadian anak. Lewat sosialisasi yang baik, anak merasa diperhatikan oleh orang tuanya sehingga dia mempunyai suatu motivasi dalam membentuk kepribadian yang baik.

Orang tua yang berpengalaman dan berpendidikan akan lebih baik dalam memberikan pendidikan kepada anak-anaknya dalam keluarga. Dapatkah ibu yang masih kekanak-kanakan itu memelihara, mendidik, dan membimbing anaknya dengan sempurna? Bagaimana bangsa kita dapat maju dan sejajar dengan bangsa lain bila putranya tidak mendapat pendidikan dan pembimbingan dengan sempurna? Seperti yang di ungkapkan oleh bapak Warno saat melakukan survei pada tgl 3 Desember 2016 pukul 15 : 23 lalu beliau mengatakan: Peran orang tua sangatlah penting terhadap anak dan pendidikan keluarga yang terdiri atas ayah, ibu, dan anak masing-masing saling mempengaruhi, saling membutuhkan, saling meladeni. Anak membutuhkan pakaian bimbingan dan sebagaianya dari orang tuanya, selama anak belum dewasa maka orang tua mempunyai peranan pertama dan utama bagi anak-anaknya". Dari pernyataan bapak Warno dapat diketahui bahwa orang tua adalah pendidikan utama bagi anak-anak, pendidikan orang tua yang baik maka akan menjadikan anak tumbuh dan berkembang sesuai dengan harapan, sebagai orang tua harus mempunyai peran dalam mendidik anak, karena anak sebagai generasi muda yang akan memajukan 
dan mengharumkan bangsa dan agama. Hal yang sama juga diungkapkan oleh salah satu staf KUA Kecamatan belitang III mengenai pendidikan anak dalam keluarga yang menikah dini pada tgl 8 Desember 2016 pukul 11:45 beliau mengatakan: Desa Nusa Bakti merupakan desa dimana jumlah perempuan lebih banyak dari pada laki-laki, jumlah perempuan hampir $60 \%$ dan laki-laki $40 \%$, banyak anak yang masih berada di usia sekolah tapi sudah tidak melanjutkan sekolah karena kurangnya perhatian dari orang tua, orang tua yang masih memikirkan diri mereka sehingga lupa dengan kewajiban kepada anaknya, selain itu ada beberapa dari mereka yang prustasi karena kedua orang tua yang bercerai sehingga mereka memilih jalan yang kurang baik". Dari peryataan staf KUA tersebut dapat diketahui bahwa jika orang tua tidak memperhatikan pendidikan anak, tidak memberikan kasih sayang, dan tidak mengawasi pergaulan anak, maka anak akan hidup sesuai kemauan mereka menjadikan masa depannya kurang baik. Sebagai orang tua seharusnya berpikir matang dan memberikan tauladan yang baik kepada anak. Menjadi orang tua bagi anak haruslah dewasa mampu menyelesaikan masalah dalam rumah tangga, mengambil keputusan yang baik untuk masa depan anak dan keluarga.

Berdasarkan latar belakang sebagaimana telah diuraikan diketahui bahwa pendidikan sangat penting bagi anak, oleh karena itu nilai-nilai pendidikan dirasa perlu diterapkan dalam keluarga sejak dini. Atas dasar hal tersebut dirumuskan bentuk penelitian deskriptif untuk mendekripsikan bagaimana dampak pernikahan dini terhadap pendidikan anak dalam keluarga.

\section{METODE/EKSPERIMEN}

Berdasarkan jenis data serta tekhnik analisis data yang digunakan, penelitian ini termasuk penelitian deskriftif kualitatif. Tehnik pengumpulan data dilakukan secara triangulasi. Analisis data bersifat induktif, dan hasil kualitatif lebih menekankan makna pada generalisasi.

Pada penelitian ini terdapat satu variabel bebas dan satu variabel terikat. Yang menjadi variabel bebas dalam penelitian ini adalah Keluarga pernikahan dini, sedangkan yang menjadi variabel terikat dalam penelitian ini adalah pendidikan anak dalam keluarga.

populsi penelitian ini adalah seluruh keluarga yang menikah dini di Desa Nusa Bakti Kecamatan Belitang III yang berjumlah 20 keluarga. Tekhnik pengambilan sampel pada penelitian ini adalah populasi/sampling jenuh Jika populasi relatif kecil kurang dari 30 orang maka semua anggota populasi digunakan sebagai sampel sehingga penelitiannya menggunakan populasi/sampling jenuh (Sugiyono, 2015:124).

\section{HASIL DAN PEMBAHASAN}

Pendidikan Anak Dalam Keluarga Yang Menikah Dini. Pendidikan merupakan hal yang sangat penting bagi kehidupan, dimana pendidikan dapat menyongsong kehidupan yang cerah dimasa depan, baik bagi diri sendiri, sosial, lingkungan, agama, nusa dan bangsa. Tanpa adanya pendidikan, kualitas diri sendiri juga akan sangat rendah, yang juga akan berpengaruh pada kualitas berbangsa dan bernegara. Anak di Desa Nusa Bakti kecamatan Belitang III merupakan suatu anugrah, karunia dan nikmat Allah yang terbesar yang harus dipelihara, tidak terkontaminasi dengan lingkngan. Oleh karena itu sebagai orang tua maka wajib membimbing dan mendidik sesuai dengan 
petunjuk Allah SWT dan Rasull-Nya, dan menjauhkan anak-anak dari pergaulan bebas wajib mencarikan lingkungan yang bagus dan teman-teman yang istiqomah.

Pendidikan anak sangat baik. Hal ini dibuktikan dari data yang diperoleh sebanyak atau seluruh anak menyatakan sangat baik dan berjumlah $100 \%$. Pendidikan yang akan melahirkan anak sholeh atau sholeha adalah pendidikan yang seimbang, yaitu pendidikan yang memperhatikan seluruh aspek, sepeti pendidikan akhlak. Pendidikan akhlak adalah dasar dari pembentukan watak dan kepribadian.

Dampak Pernikahan Dini Terhadap Pendidikan Anak Dalam Keluarga. Dampak pernikahan usia dini terhadap kualitas keturunan. Kawin dibawah umur, mudah dihinggapi bahaya, anaknya gugur, lemah atau meninggal dan tak jarang pula sang ibu muda itu yang menjadi korban. Gadis yang masih muda penuh cita-cita untuk hari depan, belum pada waktunya dibebani kewajiban-kewajiban berat, dilepas dari asuhan orang tua, diserahi mengurus rumah tangga, bahkan lebih berat lagi, dengan segala anggota tubuh yang masih muda, dengan alat kandungan yang belum cukup matang, ia harus memelihara manusia baru dalam badannya. Maka tidak heran jika karena itu banyak terjadi kekecewaan. Badan yang sedang tumbuh masih membutuhkan perkembangan-perkembangan dalam tubuhnya, tidak diberi kesempatan lebih dahulu untuk bersiap-siap, sudah dibebani dengan beban lain yang lebih berat.

Pernikahan dini sangat berdampak bagi pendidikan anak yang masih memerlukan bimbingan dari orang tua terutama orang tua yang kurang dalam memberikan kasih sayang terhadap anak, Selain itu ekonomi orang tua yang kurang memadai dapat mengganggu pendidikan anak disekolah, kurang harmonisnya keluarga dapat mengganggu mental anak, karena orang tua yang menikah dini masih memikirkan diri mereka sendiri. Pernikahan dini dapat berdampak positif dan negatif.

Dampak Positif Selama pernikahan dini diawali dengan niat yang baik untuk mengharap ridho Allah maka pernikahan dini itu akan membawa dampak yang positif seperti seorang remaja putri akan lebih muncul sifat keibuanya setelah ia menikah dan punya anak begitu juga seorang remaja putra akan lebih bertanggung jawab dan memiliki pengalaman langsung dalam rumah tangga dan membina rumah tangganya, menghindarkan diri dari perbuatan zina, pergaulan bebas dan sebagainya.

Dampak negatif Jika pada awalnya niat menikah negatif seperti halnya menutupi aib keluarganya maka akan menimbulkan hal yang negatif pula seperti KDRT (Kekerasan Dalam Rumah Tangga) yang biasa dilakukan oleh suami terhadap istrinya, pendidikan anak-anak terbengkalai karena ketidaksiapan orang tua dalam mengurus anak-anaknya, kesulitan ekonomi, dan kondisi keluarga yang kurang harmonis.

Upaya Orang Tua Dalam Mendidik Anak Dalam Keluarga Yang Menikah Dini. Orang tua adalah komponen keluarga yang terdiri dari ayah dan ibu, dan merupakan hasil dari sebuah ikatan perkawinan yang sah yang dapat membentuk sebuah keluarga di desa Nusa Bakti Kecamatan belitang III. kita sebagai orang tua harus memiliki tanggung jawab untuk mendidik anak, mengasuh dan membimbing anak-anaknya untuk mencapai tahapan tertentu yang menghantarkan anak untuk siap dalam kehidupan bermasyatakat. Orang tua di Desa Nusa Bakti Kecamatan Belitang III semua orang tua telah mempunyai upaya, upaya tersebut adalah selalu tepat waktu dalam mengerjakan 
tugas, selalu berbicara lembut kepada orang tua dan orang lain, selalu beribadah tepat waktu, memberikan motivasi, tentunya kami pun selalu memberikan contoh dengan terus menerus. Orang tua adalah pendidikan utama dan pertama dalam hal penanaman keimanan dan pengetahuan bagi anak, disebut pendidikan utama karena besar sekali pengaruhnya.

\section{PENUTUP}

Berdasarkan penelitian Dampak pernikahan dini terhadap pendidikan anak di Desa Nusa Bakti Kecamatan Belitang III dapat disimpulkan:

1. Pendidikan merupakan hal yang sangat penting bagi kehidupan, dimana pendidikan dapat menyongsong kehidupan yang cerah dimasa depan, baik bagi diri sendiri, sosial, lingkungan, agama, nusa dan bangsa. Keluarga adalah tempat pertama anggota baru belajar banyak hal, dukungan keluarga akan menjadikan anak yang tumbuh dengan penuh kasih sayang, percaya akan diri sendiri serta penuh dengan aksi pintar. Pendidikan anak di desa nusa bakti sangat baik sebagaimana diperoleh hasil dari angket bahwa seluruh anak menjawab sangat baik atau berjumlah $100 \%$.

2. Dampak pernikahan dini terhadap pendidikan anak dalam keluarga yang menikah dini di Desa Nusa Bakti Kecamatan Belitang III adalah Pernikahan dini sangat berdampak bagi pendidikan anak yang masih memerlukan bimbingan dari orang tua terutama orang tua yang kurang dalam memberikan kasih sayang terhadap anak, Selain itu ekonomi orang tua yang kurang memadai dapat mengganggu pendidikan anak disekolah, kurang harmonisnya keluarga dapat mengganggu mental anak, karena orang tua yang menikah dini masih memikirkan diri mereka sendiri.

3. Upaya orang tua tidak terlepas dari pengertian keluarga, karena orang tua merupakan bagian keluarga besar yang sebagian besar telah tergantikan oleh keluarga inti yang terdiri dari ayah dan ibu serta anak. Upaya yang dilakukan oleh orang tua yang menikah dini di Desa Nusa Bakti adalah selalu tepat waktu dalam mengerjakan tugas, selalu berbicara lembut kepada orang tua dan orang lain, selalu beribadah tepat waktu, memberikan motivasi, dan selalu memberikan contoh dengan terus menerus. Orang tua adalah pendidikan utama dan pertama dalam hal penanaman keimanan dan pengetahuan bagi anak, disebut pendidikan utama karena besar sekali pengaruhnya. Orang tua yang Menikah dini di Desa Nusa Bakti Kecamatan Belitang III telah mempunyai upaya dan telah berupaya dalam mendidik anak-anaknya dengan baik, serta telah menjalankan tugasnya dengan baik sebagai orang tua.

\section{UCAPAN TERIMAKASIH}

Terimakasih kepada Ketua STKIP Nurul Huda OKUT, Ketua LPPM STKIP Nurul Huda OKUT, Anggota Jurnal Al I'tibar STKIP Nurul Huda OKUT, Kepala Desa Nusa Bakti Kecamatan Belitang III beserta jajarannya, Dan Dosen-Dosen STKIP Nurul Huda OKUT.

\section{DAFTAR PUSTAKA}

Abidin, Slamet dan Aminudin. 1999. Fikih Munakahat. jilid.1. Bandung : Pustaka Setia 
Abu, Ahmad. 2003. IImu Sosial Dasar. Jakarta : Rineka Cipta

Ali, Z. 2010. Pengantar Keperawatan Keluarga, jakarta: EGD

Arikunto, Suharsimi. 1989. Prosedur Penelitian Suatu Pendekatan Praktek. Edisi Revisi V. Jakarta : Renika Cipta

Arifin, Zainal. 1988. Evaluasi Intruksional Prinsip-Prinsip Prosedur. Bandung : Remaja Rosda Karya.

Asrori. 2015. UU Perlindungan Anak Dengan Pernikahan. http://asrori pinanti01. Co.Id. Di Akses Tgl 31-03-2017

Ahmad Warson Al-Munawwir. 1997. Kamus Al-Munawwir Arab-Indonesia Terlengkap, Yogyakarta: Pustaka Progressif.

Direktorat Jendral kelembagaan Agama Islam.2005

Hamid, Zahry. 1998. Pokok-Pokok Hukum Perkawinan Islam Dan Undang-Undang Perkawinan Di Indonesia. Yogyakarta : Bina Cipta.

Ikhsan. 2008. Tuntutan Praktis Rumah Tangga Bahagia. Surabaya : BP-4 Jatim.

Lutfiati, 2008. Pernikahan Dini Pada Kalangan Remaja (15-19 tahun). http://nya0626.blogspot.com. Akses Tanggal 28 Maret 2017.

Marlina, M. (2016). Penguatan Peran Ibu Dalam Pendidikan Anak. Al I'tibar: Jurnal Pendidikan Islam, 2(1), 29-37.

Moleong, Lexy. J. 2012. Metode Penelitian Kualitatif. Bandung : Pt. Remaja Rosda Karya.

Nukman. (2009). Yang Dimaksud Pernikahan Dini. http://www.llhamuddin.co.cc. Akses 28 Maret 2017.

Sarwono,W Sarlito. 2016. Psikologi Remaja. Jakarta : Pt. Rajagrafindo Indonesia.

Suhendi, Hendi Dan Ramdani Wahyu. 2001. Pengantar Studi Sosiologi Keluarga. Bandung : Pustaka Setia

Suma, Muhammad Amin. 2004. Hukum Keluarga Islam Di Dunia Islam. Jakarta : PT. Raja Capindo Persada. $n$ R\&D.

Sugiyono. 2015. Metode Penelitian Kuantitatif, kualitatif dan R\&D. Bandung : Alfabeta

Suparyanto. 2011. Konsep Pernikahan Dini. Http://Dr-Suparyanto.Blogspot. Co. Id. Akses Tanggal 31-Maret-2017

Syayuti, Thalib 1998. Hukum Kekeluarga Indonesia. Jakarta : UI Press.

Yanggo, Huzaimah T dan Hafiz Anshari H.Z. (ed), 1996, Problematika Hukum Islam Kontemporer, Buku Kedua, Jakarta: PT Pustaka Firdaus. 